\title{
IAMJ
}

INTERNATIONAL

AYURVEDIC

MEDICAL JOURNAL

ISSN: 2320-5091

Impact Factor: 6.719

\section{PHARMACEUTICO-ANALYTICAL STUDY OF MALATYADI TAILA}

\author{
Yaramala Chetana $^{1}$, Ch. Sridurga ${ }^{2}$ \\ ${ }^{1}$ PG Scholar Final Year, ${ }^{2}$ M.D.(Ayu), PhD. Professor and HOD, \\ Department of Rasa Shastra and Bhaishajya Kalpana, S. V. Ayurvedic College, T.T.D, Tirupati, \\ Andhra Pradesh, India
}

Corresponding Author: chetanayaramala@gmail.com

https://doi.org/10.46607/iamj1309112021

(Published Online: November 2021)

Open Access

(C) International Ayurvedic Medical Journal, India

Article Received: 29/10//2021 - Peer Reviewed: 07/11/2021 - Accepted for Publication: 08/11/2021

\section{Check for updates}

\begin{abstract}
Analytical study of Ayurvedic preparations is the need of the present scientific era. Though the Ayurvedic drugs are time tested and have been used successfully in the management of various ailments it is now necessary to prove their quality, efficacy and safety to the scientific world through various modern analytical parameters. The Sneha Kalpa is par excellent to other dosage forms due to their wider advantages like increased absorption and extraction of fat-soluble active principles Sneha Kalpa is the only dosage form that can be administered conveniently both internally as well as externally. Malatyadi Taila is an important herbal formulation mentioned in Chakradutta for the management of the disease Darunaka.

Dandruff is an irritative disease of the scalp in which shedding of dead tissue from the scalp with itching sensation is the cardinal feature. It can be correlated to Darunaka the cardinal symptoms of the disease Darunaka are Kandu (itching), Kesha Chyuti (falling of hair), Swapa (abnormalities of touch sensation), Rukshata (roughness or dryness of the skin) and Twak Sputana (breaking or cracking of the skin). Chakradutta has mentioned the application of Malatyadi Taila in the treatment of Darunaka. An attempt has been made in the present study to prepare Malatyadi Taila and standardise it through analytical parameters like organoleptic properties, refractive index, acid value, saponification value, iodine value, loss on drying for developing standards. All the parameters were found to be good and within the standards.
\end{abstract}

Keywords: analytical standardization, Malatyadi Taila, saponification value, HPTLC. 


\section{INTRODUCTION}

Rasashastra and Bhaishajya Kalpana is the branch of Ayurvedic science that exclusively focuses on various aspects of the preparation of medicines. It is known to establish a change in the qualities and properties of the drug either by inducing a new property or improving the existing one and finally making the drug safe and more effective. Taila Kalpana (Medicated oil) is an integral part of Ayurvedic treatment and Taila can be used for both Bahya (Externally) and Abhyantara Chikitsa (Internally).

Standardization of Ayurvedic formulations is an important step for the establishment of biological activity, consistent chemical profile, or quality assurance for production. In the present study, Malatyadi taila was prepared by referring to the method described in the text Chakraduttal]and further studied organoleptically, physico-chemically and chromatographically for developing standards.

\section{MATERIALS AND METHODS}

The process was carried out in two steps:

1. Pharmaceutical Study

2. Analytical Study

\section{PROCUREMENT OF RAW MATERIALS}

- Chitraka moola was collected from Chennai Market and foreign matter adhering to raw drugs was removed and cleaned.

- Malati patra, Karaveera moola, Chitraka moola, Karanja beeja were collected from the herbal garden, S.V. Ayurveda College, TTD, Tirupati. It was then identified macroscopically and studied for important botanical characteristics.

- The base, which was used for the preparation of this taila i.e; Tila taila was also purchased from the local market.

\section{PHARMACEUTICAL STUDY}

Table 1: Showing the ingredients of Malatyadi Taila:

\begin{tabular}{|l|l|}
\hline Drugs & Quantity \\
\hline Tila taila & 1 part \\
\hline Kalka dravya: & \\
\hline Malati patra & $1 / 4^{\text {th }}$ part \\
\hline Karanja beeja & \\
\hline Suddha Chitraka moola & \\
\hline Suddha Karaveera moola & \\
\hline Jala & 4 parts \\
\hline
\end{tabular}

- As per the reference, Malatyadi taila was prepared with 1 part of Tila taila, $1 / 4^{\text {th }}$ part of Shudda Chitraka moola Churna, Shudda Karaveera moola Churna, Malati patra Churna, Karanja beeja Churna and 4 parts of Jala.

- Tila taila was taken in a wide-mouthed vessel and placed the overheating device on moderate fire. Kalka of the above-mentioned drugs was added to Tila Taila.

- Jala was added to Taila, and the contents were stirred well.
- To prevent the spillage of taila due to overflowing, a wide-mouthed large vessel was taken for the preparation.

- The colour of the taila changed from light green to dark green after paka.

- The colour change probably is an indication of solubility of active principles more into taila with the increased contact time.

- The heating was continued till the kharapaka lakshna were obtained.

- The foam was observed when Taila paka completes. 
- Kalka is hard, rough to touch and doesn't yield any Sneha on pressing.

- Khara paka is good for external application because it is devoid of moisture content. Hence it is easily absorbed through the epidermal cells.

- Then the contents were filtered through a clean cloth to obtain Malatyadi taila.

- Malatyadi Taila was transferred into bottles.

\section{ANALYTICAL STUDY Organoleptic tests:}

Organoleptic tests help in providing basic information about drugs. This generally includes tests that can be done by one's sensory organs and the quality of material can be inferred up to a limited extent.

Table 2: Showing the result of the organoleptic test of Malatyadi Taila

\begin{tabular}{|l|l|l|}
\hline S. No. & Parameter & Observation \\
\hline 1. & Colour & Greenish colour \\
\hline 2. & Odour & Characteristic \\
\hline 3. & Touch & Unctous \\
\hline 4. & Appearance & Viscous liquid \\
\hline
\end{tabular}

\section{Physicochemical tests:}

Physico-Chemical tests deal with the primary physical and chemical properties of a sample, which can hint about the internal molecular behaviours at different natural conditions. It helps in understanding the stability of a drug when it is stored for a long time. Ash tests give an idea about the organic/inorganic chemical nature of the sample. Extractive value tests help in inferring the presence of various bioactive molecules like lipids and proteins, due to their differential solubility nature in water and alcohol.

Analysed at: CENTRAL RESEARCH FACILITY, KAHER'S SRI B.M. Kankanwadi Ayurveda Mahavidyalaya, Belagavi, Karnataka.

\section{Analysis date: $1 / 01 / 21$}

Refractive Index ${ }^{1}$ :

Definition:

The refractive index $(\eta)$ of a substance with reference to air is the ratio of the sine of the angle of incidence to the sine of the angle of refraction of a beam of light passing from air into the substance. It varies with the wavelength of the light used in its measurement.

Significance: Refractive index is a fundamental physical property of a substance often used to identify a particular substance, confirm its purity, or measure its concentration. It indicates the possible chances of rancidity development in oil. The higher the refractive index higher is the chances of spoilage due to oxidation.

Result: Refractive index at $40^{\circ} \mathrm{c}$ of Malatyadi taila was $1.470 \eta$.

Acid value $^{2}$

\section{Definition:}

The acid value is defined as the number of milligrams of Potassium hydroxide required to neutralize the free fatty acids present in one gram of fat.

\section{Significance:}

It is a relative measure of rancidity as free fatty acids are normally formed during the decomposition of triglycerides.

It is one of the important parameters related to oil quality. A high AV indicates the deterioration of the oil, which affects its nutritive value.

Result: Acid value of the drug was $5.80 \% v / w$.

\section{Saponification value ${ }^{3}$}

Definition: The saponification value is defined as the amount of potassium hydroxide $(\mathrm{KOH})$ in milligrams required to saponify one gram of fat or oil under the conditions specified.

Significance: To know how many acids (esters and free acids) are contained in a fat or oil. The greater the number of saponification, the more short- and medium-chain fatty acids the fat contains. In general, the saponification value of plant origin oils ranges from $188-196 \mathrm{mg} / \mathrm{g}$. 
Result: The saponification value of the drug was $99.70 \% \mathrm{v} / w$.

Iodine value $^{4}$

Definition: The Iodine value is defined as the number of grams of iodine absorbed by $100 \mathrm{~g}$ of fat.

Significance: It indicates the degree of unsaturation of fat or oil.

Result: The iodine value of Malatyadi taila is $119.46 \% \mathrm{v} / \mathrm{w}$, indicating the acidic nature.

\section{Loss on drying ${ }^{5}$}

Definition: Loss on drying compares the weight of the product sample before and after drying. It refers to the loss of any volatile material from the sample.

Significance: Loss on drying not only measure content but also quantify any other volatile principles in a given sample. This value determines the quantity of moisture a given sample contains. Stability, shelf life and microbiological safety depend on this value

Result: Loss on drying of Malatyadi taila is $\mathbf{1 . 3 3 0 \%}$ v/w.

\section{Microbial Contamination}

Microbial contamination is determined by the total viable aerobic count, which is the sum of the bacterial count and the fungal count. The tests allow quantitative enumeration of mesophilic bacteria and fungi that may grow under aerobic conditions. Membrane filtration, plate count methods and mostprobable-number method are used for the determination of total viable aerobic count. According to IP the acceptance limit for this is not more than $10^{3}$ bacteria and not more than 102 fungi per $\mathrm{g}$ or $\mathrm{ml}$ of the preparation.

Result: Total bacterial count and fungal count of Malatyadi Taila is less than $10 \mathrm{CFU} / \mathrm{ml}$.

\section{High-performance thin-layer chromatography (HPTLC)}

High-performance thin-layer chromatography (HPTLC) is an enhanced form of thin-layer chromatography (TLC). Several enhancements can be made to the basic method of thin-layer chromatography to automate the different steps, to increase the resolution achieved and to allow more accurate quantitative measurements.

Automation is useful to overcome the uncertainty in droplet size and position when the sample is applied to the TLC plate by hand. One recent approach to automation has been the use of piezoelectric devices and inkjet printers for applying the sample.

The spot capacity (analogous to peak capacity in (HPTLC) can be increased by developing the plate with two different solvents, using two-dimensional chromatography. The procedure begins with the development of a sample loaded plate with the first solvent. After removing it, the plate is rotated $90^{\circ}$ and developed with a second solvent.

Result: At short UV 254nm Malatyadi Taila sample was seen, and 7 bands were observed at Rf values of $0.08,0.17,0.26,0.28,0.38,0.43$ and 0.45 with green colour intensity.

At long UV 366nm, Malatyadi Taila sample was seen, and 8 bands were spotted with different $\mathrm{Rf}$ values of $0.01,0.04,0.09,0.12,0.17,0.21,0.25$, 0.29 and spotted with colour intensities of Cyan, Cyan, Blue, Teal, Blue, Cyan, Blue, Red respectively.

After derivatisation with sulphuric acid, at UV $520 \mathrm{~nm}$ there are 7 bands spotted with different colour intensities with $\mathrm{Rf}$ values of $0.04,0.11,0.16$, $0.22,0.29,0.38$ and 0.44 , and spotted with colour intensities of Black, Blue Violet, Blue Violet, Blue Violet, Light Black, Black and Black respectively. 


\section{Result:}

Table 3: Showing the result of HPTLC of Malatyadi Taila

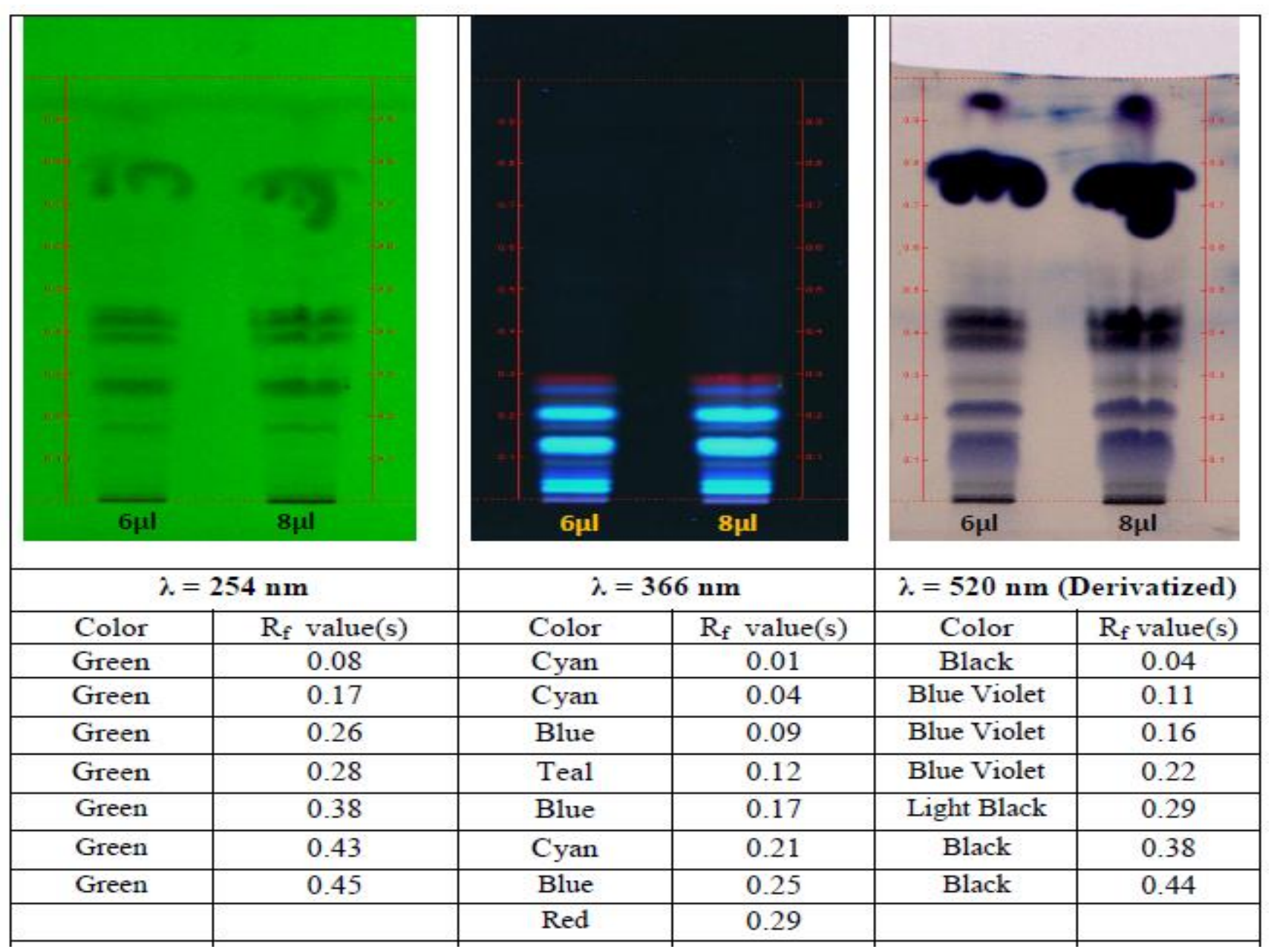


Graph 1: Showing peaks@254nm of Malatyadi taila

\begin{tabular}{|c|c|c|c|c|c|c|c|c|c|}
\hline Peak & $\begin{array}{c}\text { Start } \\
\text { Position }\end{array}$ & $\begin{array}{c}\text { Start } \\
\text { Height }\end{array}$ & $\begin{array}{c}\text { Max } \\
\text { Position }\end{array}$ & $\begin{array}{c}\text { Max } \\
\text { Height }\end{array}$ & $\begin{array}{c}\operatorname{Max} \\
\%\end{array}$ & $\begin{array}{c}\text { End } \\
\text { Position }\end{array}$ & $\begin{array}{c}\text { End } \\
\text { Height }\end{array}$ & Area & $\begin{array}{c}\text { Area } \\
\%\end{array}$ \\
\hline 1 & $0.08 \mathrm{Rf}$ & $0.7 \mathrm{AU}$ & $0.10 \mathrm{Rf}$ & 11.7 AU & $1.23 \%$ & $0.12 \mathrm{Rf}$ & $0.2 \mathrm{AU}$ & 146.6 AU & $0.47 \%$ \\
\hline 2 & $0.12 \mathrm{Rf}$ & $0.3 \mathrm{AU}$ & $0.15 \mathrm{Rf}$ & $24.3 \mathrm{AU}$ & $2.55 \%$ & $0.16 \mathrm{Rf}$ & $19.7 \mathrm{AU}$ & $409.5 \mathrm{AU}$ & $1.32 \%$ \\
\hline 3 & $0.16 \mathrm{Rf}$ & $20.6 \mathrm{AU}$ & $0.18 \mathrm{Rf}$ & $80.3 \mathrm{AU}$ & $8.43 \%$ & $0.20 \mathrm{Rf}$ & $21.8 \mathrm{AU}$ & $1718.3 \mathrm{AU}$ & $5.54 \%$ \\
\hline 4 & $0.21 \mathrm{Rf}$ & $22.1 \mathrm{AU}$ & $0.22 \mathrm{Rf}$ & $34.5 \mathrm{AU}$ & $3.63 \%$ & $0.23 \mathrm{Rf}$ & $18.6 \mathrm{AU}$ & $624.6 \mathrm{AU}$ & $2.01 \%$ \\
\hline 5 & $0.24 \mathrm{Rf}$ & $18.6 \mathrm{AU}$ & $0.29 \mathrm{Rf}$ & $232.7 \mathrm{AU}$ & $24.43 \%$ & $0.36 \mathrm{Rf}$ & $12.0 \mathrm{AU}$ & $8331.9 \mathrm{AU}$ & $26.86 \%$ \\
\hline 6 & $0.36 \mathrm{Rf}$ & $12.2 \mathrm{AU}$ & $0.41 \mathrm{Rf}$ & $191.2 \mathrm{AU}$ & $20.08 \%$ & $0.43 \mathrm{Rf}$ & $26.8 \mathrm{AU}$ & $5148.9 \mathrm{AU}$ & $16.60 \%$ \\
\hline 7 & $0.43 \mathrm{Rf}$ & $127.5 \mathrm{AU}$ & $0.45 \mathrm{Rf}$ & $194.0 \mathrm{AU}$ & $20.37 \%$ & $0.52 \mathrm{Rf}$ & $0.5 \mathrm{AU}$ & $6807.0 \mathrm{AU}$ & $21.95 \%$ \\
\hline 8 & $0.52 \mathrm{Rf}$ & $0.5 \mathrm{AU}$ & $0.55 \mathrm{Rf}$ & $15.0 \mathrm{AU}$ & $1.58 \%$ & $0.58 \mathrm{Rf}$ & $3.2 \mathrm{AU}$ & $380.2 \mathrm{AU}$ & $1.23 \%$ \\
\hline 9 & $0.63 \mathrm{Rf}$ & $1.9 \mathrm{AU}$ & $0.66 \mathrm{Rf}$ & $12.5 \mathrm{AU}$ & $1.31 \%$ & $0.71 \mathrm{Rf}$ & $1.1 \mathrm{AU}$ & $422.2 \mathrm{AU}$ & $1.36 \%$ \\
\hline 10 & $0.74 \mathrm{Rf}$ & $0.1 \mathrm{AU}$ & $0.81 \mathrm{Rf}$ & 113.2 AU & $11.89 \%$ & $0.87 \mathrm{Rf}$ & $5.6 \mathrm{AU}$ & 5516.3 AU & $17.78 \%$ \\
\hline 11 & $0.91 \mathrm{Rf}$ & $1.9 \mathrm{AU}$ & $0.97 \mathrm{Rf}$ & $42.9 \mathrm{AU}$ & $4.51 \%$ & $1.00 \mathrm{Rf}$ & $2.0 \mathrm{AU}$ & 1511.2 AU & $4.87 \%$ \\
\hline
\end{tabular}

\section{DISCUSSION}

The analytical study is an essential part of any research work. It provides us with experimental data (qualitative and quantitative) and makes us know about the certainty of our assumptions and prevents from miss interpretations. It provides us with complete knowledge of our formulation like identity, size, the structure of chemical constituents and physical properties. It hints to us about the toxic properties of drugs, if any.

\section{Organoleptic tests:}

- Organoleptic tests of a substance are done with the help of sense organs. It plays a major role when the medicine is ingested orally.

- The greenish colour of the final product is due to the boiling of ingredients in Taila.

- Characteristic odour.

- Unctuous touch of the formulation indicates the proper preparation of Taila.

\section{Physico - Chemical tests:}

Investigating Physico-Chemical systems makes it possible to determine the nature of interactions between the components of the sample through a study of the relationship between sample physical properties and composition.

\section{CONCLUSION}

Malatyadi taila is one of the taila mentioned for treatment of Darunaka. A detailed method of preparation is available in Chakradutta.With that classical reference in backdrop, Malatyadi taila was prepared in lines with standard operating procedures (SOP) and subjected to different analysis thereon. The result of an analytical study with HPTLC has been proposed as a monograph to identify and check the quality of Malatyadi taila.

\section{REFERENCES}

1. The Ayurvedic Pharmacopoeia of India Part II Vol II First Edition, Ministry of Health and Family Welfare Government of India Department of (AYUSH), New Delhi, Published by The Controller of publications Civil Lines, 2008, appendix 3/3.1

2. The Ayurvedic Pharmacopoeia of India Part II Vol II First Edition, Ministry of Health and Family Welfare Government of India Department of (AYUSH), New Delhi, Published by The Controller of publications Civil Lines,2008, appendix 2/2.2.4

3. The Ayurvedic Pharmacopoeia of India Part II Vol II First Edition, Ministry of Health and Family Welfare Government of India Department of (AYUSH), New 
Delhi, Published by The Controller of publications Civil Lines, 2008, appendix $3 / 3.10$

4. The Ayurvedic Pharmacopoeia of India Part II Vol II First Edition, Ministry of Health and Family Welfare Government of India Department of (AYUSH), New Delhi, Published by The Controller of publications Civil Lines,2008, appendix 3/3.11
5. The Ayurvedic Pharmacopoeia of India Part II Vol II First Edition, Ministry of Health and Family Welfare Government of India Department of (AYUSH), New Delhi, Published by The Controller of publications Civil Lines,2008, appendix 2/2.2.10

\section{Source of Support: Nil}

\section{Conflict of Interest: None Declared}

How to cite this URL: Yaramala Chetana \& Ch. Sridurga: Pharmaceutico-Analytical Study Of Malatyadi Taila. International Ayurvedic Medical Journal \{online\} 2021 \{cited November 2021\} Available from: http://www.iamj.in/posts/images/upload/ 2729 2735.pdf 